\title{
PENERAPAN MODEL MASTERY LEARNING DALAM MENINGKATKAN PEMAHAMAN MATEMATIK SISWA
}

\author{
Hismi Hadria Setiawati ${ }^{1}$, Agus Hikmat Syaf ${ }^{2}$ \\ ${ }^{\prime}$ Sekolah Dasar Plus Baiturrahman Bandung, Jawa Barat, Indonesia \\ ${ }^{2} J u r u s a n$ Pendidikan Matematika, UIN Sunan Gunung Djati, Bandung, Indonesia \\ hadriaaa96@gmail.com
}

Naskah diterima: tanggal 16 Juli 2018, direvisi: tanggal 30 Juli 2018, diterbitkan: tanggal 31 Oktober 2018

\begin{abstract}
This purpose of this research is to know the implementation of the Mastery Learning to improve the ability of mathematic in every cycles, and rising of activities in learning process through Mastery Learning. The methodolgy in this research is Classroom Action Research (CAR) which consists of two cycles, whereby in each cycle consists of planning, action, observation, and reflection. Subject of this research is students of class IV (grade four) MIN 1 Bandung, West Java Indonesia. The results in this research is the implementation of Mastery Learning in each cycles by teachers and students increased sharply. In addition, the average mathematical ability of students in the first cycle which is 79.75 , and in the second cycle is 83.85 , furthermore the rate of mathematical ability in the last cycle is 86,7 (a very large majority). Thus, the application of Mastery Learning can improve students' mathematical ability.
\end{abstract}

Keywords: Mastery Learning, Mathematic, Madrasah Ibtidaiyah

\section{ABSTRAK}

Penelitian ini dilakukan dengan tujuan untuk mengetahui keterlaksanaan penerapan model Mastery Learning untuk meningkatkan kemampuan pemahaman matematik dalam mata pelajaran matematika di kelas pada setiap siklus, peningkatan kemampuan pemahaman matematik siswa dalam mata pelajaran matematika dengan penerapan model Mastery Learning pada setiap siklus, dan kemampuan pemahaman matematik siswa dalam mata pelajaran matematika setelah menggunakan model Mastery Learning pada kelas pada akhir siklus. Metode yang digunakan pada penelitian ini adalah Penelitian Tindakan Kelas (PTK) yang terdiri dari dua siklus, dimana setiap siklusnya terdiri dari perencanaan, pelaksanaan tindakan, observasi, dan refleksi. Subjek penelitian ini adalah siswa kelas IV C MIN 1 Kota Bandung. Berdasarkan hasil penelitian yang diperoleh dapat disimpulkan sebagai berikut: 1) keterlaksanaan penerapan model Mastery Learning untuk aktivitas guru pada siklus II sebesar 94\% dan aktivitas siswa pada siklus II sebesar $88 \%$; 2) ratarata pemahaman matematik siswa pada siklus I sebesar 79,75, dan pemahaman pada siklus II sebesar 83,85 ; 3) rata-rata pemahaman matematik siswa pada akhir siklus yaitu 86,7 dengan kategori baik. Maka, hipotesis penelitian terbukti bahwa penerapan model Mastery Learning dapat meningkatkan pemahaman matematik siswa.

Kata Kunci: Mastery Learning, Pemahaman Matematika, Madrasah Ibtidaiyah

\section{PENDAHULUAN}

Pembelajaran matematika di Madrasah Ibtidaiyah (MI) merupakan salah satu kajian yang selalu menarik untuk dikemukakan karena adanya perbedaan karakteristik khususnya antara hakikat anak dan hakikat matematika. Perbedaan tersebut yaitu cara berpikir siswa MI yang berada pada tahap pra-konkret sedangkan hakikat matematika bersifat abstrak. Perbedaan tersebut tentu merupakan hal yang perlu diperhatikan oleh guru karena guru merupakan fasilitator antara siswa dengan pembelajaran matematika. 
Guru sebagai tenaga pengajar yang menentukan keberhasilan pembelajaran matematika di sekolah harus mampu menghadapi perbedaan karakteristik dari setiap siswa yang diajarkannya. Pembelajaran matematika dengan berpusat pada guru (teacher centered) harus diganti menjadi berpusat pada siswa (student centered), dimana pada proses pembelajaran guru hanya bertidak sebagai fasilitator yang membuat perubahan pada siswa dari tidak paham menjadi paham. Pembelajaran matematika yang baik adalah pembelajaran didominasi oleh guru tetapi dapat membuat siswa memahami dengan baik konsep materi tersebut.

Pemahaman yang baik tentu sangat diperlukan terutama pada pembelajaran matematika. Pemahaman matematis yang baik tentu akan membuat hasil belajar siswa lebih baik pula. Kemampuan pemahaman matematik menurut Karunia Eka Lestari (Lestari, 2015) merupakan kemampuan menyerap dan memahami ide-ide matematika. Kemampuan ini berarti bahwa siswa bukan hanya mengenal materi tetapi juga memahami konsep atau ide dari materi tersebut. Pemahaman matematis diperlukan oleh siswa agar mampu berpikir kritis sebab pada pemahaman matematis siswa dituntut untuk mampu mengidentifikasi dan menerjemahkan soal. Kemampuan tersebut diperlukan siswa agar dapat menerapkan konsep matematika pada kehidupan sehari-hari.

Perbedaan karakteristik matematika yang abstrak dan siswa MI yang masih berpikir konkret membuat banyak guru matematika sulit menemukan model pembelajaran yang tepat uutuk diterapkan pada pembelajaran matematika, sehingga siswa tidak memahami konsep dari materi yang diajarkan oleh guru tersebut. Berdasarkan studi pendahuluan di MIN 1 Kota Bandung, permasalahan dalam pembelajaran matematika masi ditemukan, khususnya di kelas IV C, bahwa pemahaman matematik siswa masih rendah, terlihat dari nilai tes siswa yang masih banyak mendapat nilai dibawah KKM (Kriteria Ketuntasan Minimal). Rata-rata pemahaman siswa hanya 63, masih jauh dari standar KKM yaitu 70. Hal ini disebabkan selama proses pembelajaran guru menggunakan model pembelajaran yang bersifat monoton sehingga menyebabkan pemahaman matematik siswa sangat rendah.

Tujuan penelitian ini adalah untuk mengetahui (1) Keterlaksanaan penerapan Model Mastery Learning untuk meningkatkan kemampuan pemahaman matematik dalam mata pelajaran matematika di kelas IV C MIN 1 Kota Bandung pada setiap siklus (2) Peningkatan kemampuan pemahaman matematik siswa dalam mata pelajaran matematika dengan penerapan model Mastery Learning di kelas IV C MIN 1 Kota Bandung pada setiap siklus (3) Kemampuan pemahaman matematik siswa dalam mata pelajaran matematika setelah menggunakan model Mastery Learning pada kelas IV C MIN 1 Kota Bandung pada akhir siklus.

Penelitian ini didasarkan pada pemikiran bahwa pemahaman belajar siswa ditentukan oleh banyak faktor salah satunya penerapan model yang tepat. Menurut teori Brownell siswa akan lebih memahami suatu konsep materi apabila diberikan pengulangan latihan/ ulangan. Matematika yang bersifat abstrak akan lebih dipahami apabila siswa diberikan latihan/pengulangan supaya siswa terbiasa mengerjakan penerapan soal pada materi tersebut. Maka dari itu, perlu diberikan model pembelajaran yang bersifat latihan untuk dijadikan solusi pada permasalahan tersebut, salah satunya dengan model pembelajaran Mastery Learning.

Model Mastery Learning (Joyce, 2009) adalah model pembelajaran yang menarik dan ringkas untuk dapat meningkatkan unjuk kerja siswa ke tingkat pencapaian suatu pokok bahasan yang lebih memuaskan. Dimana Mastery Learning mengharuskan siswa memahami suatu pokok bahasan untuk dapat lanjut ke pokok bahasan berikutnya. 
Sedangkan menurut Groen Mastery Learning mendukung kepercayaan bahwa semua siswa dapat belajar dan mencapai tingkatan konten yang sama ketika disediakan kondisi pembelajaran dengan tepat (termasuk waktu). Mastery Learning didefinisikan dalam istilah subjek objek dan prestasi dari menentukan tingkatan dari kinerja, kompetensi, dalam kriteria tes (Groen et al., 2015).

Model Mastery Learning sendiri terdiri dari lima langkah, yaitu: (1) Orientasi (2) Penyajian materi, (3) latihan terstruktur, (4) latihan terbimbing, dan (5) latihan mandiri. Mastery Learning membiasakan siswa untuk berlatih mengerjakan soal agar konsep materi yang dipelajari dapat dipahami dengan baik.

\section{METODOLOGI}

Penelitian ini menggunakan pendekatan penelitian mixed methods, yaitu salah satu pendekatan penelitian yang melibatkan pengumpulan data baik informasi numerik maupun informasi teks sehingga database akhir mempresentasikan baik informasi kuantitatif maupun kualitatif. Pendekatan mixed methods dipilih karena penelitian ini melakukan pengumpulan data secara kuantitatif dan kualitatif (Emzir, 2013). Dimana data kuantitatif (informasi numerik) didapatkan melalui instrumen tes dan data kualitatif (informasi teks) didapatkan melalui observasi didalam kelas.

Lokasi penelitian ini dilaksanakan di MIN 1 Kota Bandung, Jawa Barat pada bulan Februari-April 2018. Subjek utama penelitian adalah siswa kelas IV C berjumlah 43 siswa, yang terdiri dari 19 orang siswa laki-laki dan 24 orang siswa perempuan.

Penelitian ini berjenis Penelitian Tindakan Kelas (PTK) dengan dua siklus berulang dimana setiap siklus terdiri dari empat langkah yaitu: (1) perencanaan (2) tindakan (3) observasi (4) refleksi. PTK merupakan penelitian dengan fokus utama berupa tindakan guru di kelas, dengan tujuan untuk memecahkan masalah pada proses belajar mengajar. PTK dipilih karena penelitian ini dilakukan untuk memperbaiki proses belajar mengajar agar menjadi lebih baik lagi, serta dapat meningkatkan pemahaman matematis siswa melalui perencanaan,tindakan, observasi dan refleksi. Untuk gambaran siklus penelitian dapat terlihat pada gambar 1 .

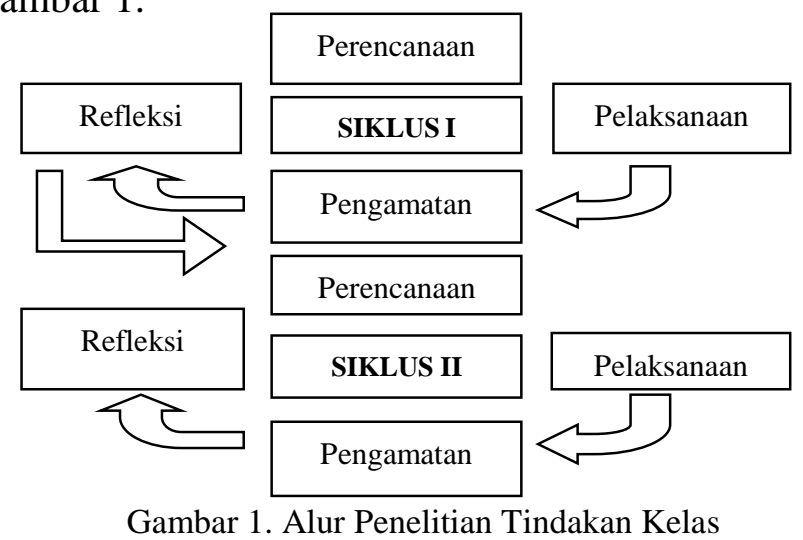

Teknik analisis data tes dapat dilihat dari hasil instrumen tes yang yang diberikan kepada siswa pada setiap tindakannya. Instrumen tes ini dibuat sesuai indikator pemahaman relasional yang disesuaikan dengan pemahaman matematika untuk siswa MI. Adapun untuk mengetahui nilai rata-rata pemahaman matematis siswa digunakan rumus. 


$$
\overline{\mathrm{X}}=\frac{\sum X}{\sum N}
$$

Keterangan :

$$
\begin{aligned}
& \mathrm{X}: \text { Nilai rata-rata } \\
& \sum X: \text { Jumlah semua nilai siswa } \\
& \sum N \text { : Jumlah siswa }
\end{aligned}
$$

Tabel 1. Kriteria Tingkat Keberhasilan Belajar Siswa

\begin{tabular}{|c|c|}
\hline Tingkat Keberhasilan & Klasifikasi \\
\hline $90 \leq \mathrm{A} \leq 100$ & Istimewa \\
\hline $75 \leq \mathrm{B}<90$ & Baik \\
\hline $55 \leq \mathrm{C}<74$ & Cukup \\
\hline $40 \leq \mathrm{D}<54$ & Kurang \\
\hline $00 \leq \mathrm{E}<39$ & Kurang Sekali \\
\hline
\end{tabular}

Selain digunakan analisis dengan menentukan rata-rata pemahaman matematik siswa, digunakan pula analisis ketuntasan belajar secara individu ini digunakan untuk mengetahui siswa mana yang sudah tuntas belajar dan siswa mana yang belum tuntas belajar. Kriteria ketuntasan disesuaikan dengan KKM mata pelajaran matematika yang ditetapkan MIN 1 Kota Bandung yaitu 70. Sedangkan ketuntasan klasikal digunakan untuk menganalisis ketuntasan secara keseluruhan dalam satu kelas. Secara proporsional, sebuah kelas dinyatakan telah tuntas belajar secara klasikal jika $80 \%$ dari jumlah siswa kelas itu telah memperoleh nilai lebih sama dengan 70 . Sedangkan untuk mengetahui ketuntasan belajar siswa dan daya serap belajar siswa, sebagai berikut:

a) Ketuntasan Belajar Secara Individu (KI)

$$
\mathrm{KI}=\frac{\text { Jumlah } \text { jawaban benar }}{\text { jumlah skor maksimal }} \times 100
$$

b) Ketuntasan Belajar Secara Klasikal (KK)

$$
\mathrm{KK}=\frac{\text { Jumlah siswa yang memperoleh nilai } \geq 70}{\text { Jumlah seluruh siswa }} \times 100 \%
$$

(Hayati, 2013)

Sedangkan untuk pengolahan data observasi dapat dilihat dari penilaian pada lembar observasi aktivitas guru dan aktivitas siswa. Untuk melihat kriteria aktivitas siswa selama proses pembelajaran dihitung dengan rumus:

Persentase Aktivitas $=\frac{\text { Jumlah aktivitas yang tercapai }}{\text { Seluruh aktivitas }} \times 100 \%$

Kriteria penilaian untuk persentase skor aktivitas siswa dan guru pada tabel 2, sebagai berikut:

Tabel 2. Persentase Aktivitas

\begin{tabular}{|c|c|c|}
\hline Persentase (\%) & Bobot & Kategori \\
\hline $86-100$ & 4 & Sangat baik \\
\hline $76-85$ & 3 & Baik \\
\hline $60-75$ & 2 & Sedang \\
\hline $55-59$ & 1 & Kurang \\
\hline$\leq 54$ & 0 & Sangat kurang \\
\hline
\end{tabular}

\section{HASIL DAN DISKUSI}

Hasil penelitian diawali dengan penilaian dari aktivitas guru dan aktivitas siswa pada penerapan model Mastery Learning dalam mata pelajaran matematika. Kegiatan penerapan model diawali dengan dilakukannya tindakan 1 siklus I dengan menerapkan model 
pembelajaran Mastery Learning pada materi Faktor Persekutuan Terbesar (FPB) dan menyelesaikan masalah sehari-hari yang berhubungan dengan materi FPB.

Pada tindakan 1 siklus I ini aktivitas siswa sebesar 60\% dan aktivitas guru sebesar 83\%. Pada tindakan 2 siklus I aktivitas siswa meningkat menjadi 83\% dan aktivitas guru menjadi 92\%. Pada tindakan 1 siklus II aktivitas siswa meningkat menjadi $86 \%$ dan aktivitas guru menjadi 97\%. Pada tindakan 2 siklus II aktivitas siswa meningkat menjadi 90\% dan aktivitas guru menjadi 100\%. Untuk lebih jelasnya persentase aktivitas guru dan aktivitas siswa selama penerapan model Mastery Learning dapat dilihat pada tabel berikut.

Tabel 3. Data Persentase Aktivitas Guru dan Aktivitas Siswa

\begin{tabular}{|c|c|c|c|c|c|c|}
\hline & $\begin{array}{c}\text { Tindakan 1 } \\
\text { Siklus I }\end{array}$ & $\begin{array}{c}\text { Tindakan 2 } \\
\text { Siklus I }\end{array}$ & $\begin{array}{c}\text { Rata-rata } \\
\text { Siklus I }\end{array}$ & $\begin{array}{c}\text { Tindakan 1 } \\
\text { Siklus II }\end{array}$ & $\begin{array}{c}\text { Tindakan } \\
\text { 2 Siklus II }\end{array}$ & $\begin{array}{c}\text { Rata-rata } \\
\text { Siklus II }\end{array}$ \\
\hline $\begin{array}{c}\text { Aktivitas } \\
\text { Guru }\end{array}$ & $83 \%$ & $92 \%$ & $88 \%$ & $97 \%$ & $100 \%$ & $94 \%$ \\
\hline $\begin{array}{c}\text { Aktivitas } \\
\text { Siswa }\end{array}$ & $60 \%$ & $83 \%$ & $72 \%$ & $86 \%$ & $90 \%$ & $88 \%$ \\
\hline
\end{tabular}

Sedangkan untuk persentase peningkatan aktivitas belajar siswa pada keterlaksanaan penerapan model Mastery Learning dalam mata pelajaran matematika pada setiap siklusnya dapat terlihat pada gambar 2 .

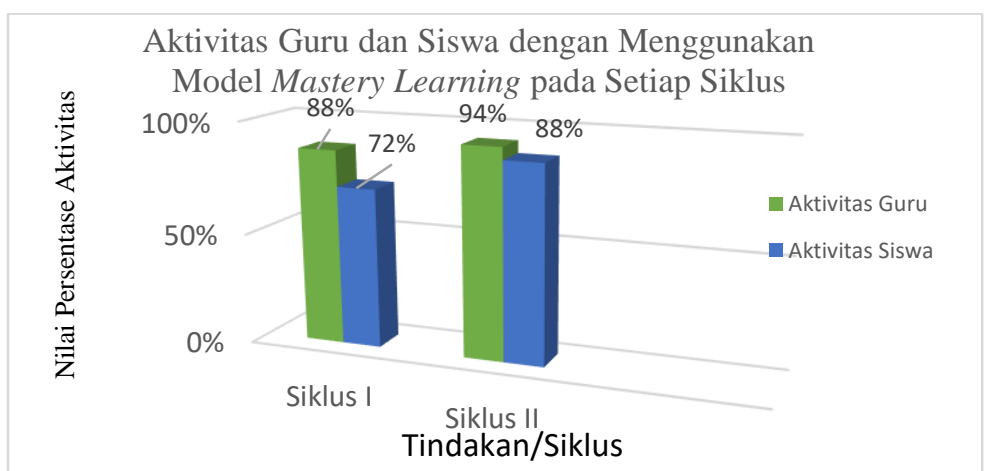

Gambar 2. Aktivitas Guru dan Aktivitas Siswa dengan Menggunakann Model Mastery Learning pada Setiap Siklus

Pada siklus II aktivitas guru 94\% dengan kategori sangat baik dan aktivitas siswa 88\% dengan kategori sangat baik pula. Peningkatan yang terjadi membuktikan bahwa dengan menggunakan model pembelajaran Mastery Learning guru yang bertindak sebagai fasilitator sudah dapat membimbing dan memotivasi siswa untuk lebih aktif dalam proses pembelajaran. pada siklus I sebesar $72 \%$ dan siklus II sebesar $88 \%$. Rata-rata aktivitas siswa dari siklus I ke siklus II mengalami peningkatan sebesar $16 \%$ dengan kategori sangat baik. Hal ini berarti siswa telah mampu untuk melakukan tugasnya dan antusias saat pembelajaran berlangsung.

Tujuan utama dari penelitian ini adalah untuk meningkatkan pemahaman matematik siswa. Aspek kognitif dalam pembelajaran matematika mencakup perilaku-perilaku yang menekan aspek intelektual seperti kemampuan matematik (mathemtical abilities), yaitu pengetahuan dan keterampilan dasar yang diperlukan untuk dapat melakukan manipulasi matematka dan kemampuan berpikir dalam matematika. Salah satu kemampuan matematik tersebut ialah kemampuan pemahaman matematik (Understanding).

Kemampuan pemahaman matematik menurut Karunia Eka Lestari (Lestari, 2015) merupakan kemampuan menyerap dan memahami ide-ide matematika. Kemampuan ini 
berarti bahwa siswa bukan hanya mengenal materi tetapi juga memahami konsep atau ide dari materi tersebut. Kemampuan pemahaman matematis memiliki tingkat lebih tinggi dibandingkan dengan kemampuan pengetahuan matematis, dimana pada kemampuan pengetahuan siswa hanya dituntut untuk bisa mengenal dan mengingat, tetapi pada kemampuan pemahaman siswa dituntut untuk mampu mengidentifikasi dan menerjemahkan soal. Kemampuan pemahaman matematis terbagi lagi, salah satunya adalah pemahaman relasional yang berarti siswa dapat mengaitkan sesutau dengan hal lainnya secara benar dan menyadari proses yang dilakukannya.

Contoh soal pada pemahaman matematis cenderung berbentuk cerita hal ini dimaksudkan agar siswa mampu mengidentifikasi dan menerjemahkan soal tersebut. Contoh soalnya sebagai berikut:

Rangga berlatih renang setiap 4 hari sekali, Ito berlatih dayung setiap 6 hari sekali, dan Luqman memancing setiap 9 hari sekali. Setiap berapa hari ketiganya akan berlatih secara bersama-sama?

Soal cerita diatas menuntut siswa untuk terlebih dahulu menerjemakan soal tersebut agar mengetahui apa yang diketahui dan ditanyakan dari soal tersebut baru kemudian memikirkan bagaimana cara menjawabnya. Adapun indikator pemahaman yang digunakan dalam penelitian ini adalah pemahaman relasional. Indikator pemahaman relasional disesuaikan dengan pemahaman matematik siswa MI, maka yang digunakan sebagai berikut:

1. Kemampuan menerapkan rumus pada permasalahan matematika.

2. Kemampuan melaksanakan perhitungan secara algoritma.

3. Kemampuan menyajikan dan menyatakan ulang konsep matematika yang dipelajari.

4. Kemampuan mengkaitkan konsep matematika dengan konsep matematika yang lain.

Pada penelitian ini tes yang diberikan kepada siswa sesuai dengan indikator pemahaman relasional diatas dengan bentuk soal cerita atau uraian. Untuk mengetahui peningkatan pemahaman matematik siswa pada mata pelajaran matematika dengan menggunakan model Mastery Learning peneliti memberikan tes pada setiap tindakan.

Setelah proses pembelajaran matematika diterapkan model Mastery Learning terlihat pemahaman matematis siswa dan ketuntasan klasikal mengalami peningkatan pada setiap pertemuannya. Untuk pemahaman matematik siswa pada tidakan 1 siklus I ialah dengan 79 kriteria penilaian baik karena terletak pada interval $75 \leq \mathrm{B}<95$. Pada tindakan 2 siklus I kemampuan pemahamannya naik menjadi 80,5 dengan kriteria baik. Maka untuk mengetahui pemahaman matematik siswa pada siklus I dapat dirata-ratakan sebagai berikut.

$$
\begin{aligned}
& =\frac{\text { pemahaman matematik } 1+\text { pemahaman matematik } 2}{2} \\
& =\frac{79+80,5}{2}=\frac{159,5}{2}=79,75
\end{aligned}
$$

Maka pemahaman matematik siswa untuk siklus I ialah 79,75 dengan kriteria baik karena terletak pada interval $75 \leq \mathrm{B}<95$.

Berdasarkan hasil penelitian nilai ketuntasan klasikal pada tindakan 1 dan 2 siklus I, dengan hasil pada tindakan 1 sebesar $74,4 \%$ dan tindakan 2 sebesar 72,1\%, maka ketentuntasan klasikal pada siklus I dapat dirata-ratakan sebagai berikut:

$$
\begin{aligned}
& =\frac{\text { Ketuntasan klasikal tindakan } 1+\text { ketuntasan klasikal tindakan } 2}{2} \\
& =\frac{74,4 \%+72,1 \%}{2}=\frac{151,1 \%}{2}=73,25 \%
\end{aligned}
$$


Dengan berdasar pada kriteria bahwa sebuah kelas dinyatakan telah tuntas belajar (Mastery) secara klasikal jika $80 \%$ dari jumlah siswa dikelas tersebut telah mencapai ketuntasan belajar lebih dari atau sama dengan 70. Karena ketuntasan klasikal pada siklus I hanya 73,25\%, maka siswa IV MIN 1 Kota Bandung belum mencapai ketuntasan belajar klasikal, ini artinya masih ada siswa yang nilainya belum mencapai ketuntasan individu. Maka dari itu, peneliti melanjutkan treatment dengan melakukan siklus II.

Pada siklus II nilai ketuntasan klasikal pada tindakan 1 dan 2 meningkat, dengan hasil pada tindakan 1 sebesar 79,1\% dan tindakan 2 sebesar $100 \%$, maka dapat dirataratakan sebagai berikut:

$$
\begin{aligned}
& =\frac{\text { Ketuntasan klasikal tindakan } 1+\text { ketuntasan klasikal tindakan } 2}{2} \\
& =\frac{79,1 \%+100 \%}{2}=\frac{179,1 \%}{2}=89,55 \%
\end{aligned}
$$

Berdasarkan kriteria bahwa sebuah kelas dinyatakan telah tuntas belajar (Mastery) secara klasikal jika $80 \%$ dari jumlah siswa dikelas tersebut telah mencapai ketuntasan belajar lebih dari atau sama dengan 70 . Ketuntasan klasikal pada siklus II adalah 89,55\% maka, siswa kelas IV MIN 1 Kota Bandung telah mencapai ketuntasan belajar klasikal.

Untuk pemahaman matematik siswa pada tidakan 1 ialah dengan 81,1 kriteria penilaian baik karena terletak pada interval $75 \leq \mathrm{B}<95$. Pada tindakan 2 kemampuan pemahamannya meningkat menjadi 86,6 dengan kriteria baik. Maka untuk mengetahui pemahaman matematik siswa pada siklus II dapat dirata-ratakan sebagai berikut.

$$
\begin{aligned}
& =\frac{\text { pemahaman matematik } 1+\text { pemahaman matematik } 2}{2} \\
& =\frac{81,1+86,6}{2}=\frac{167,7}{2}=83,85
\end{aligned}
$$

Maka pemahaman matematik siswa untuk siklus II ialah 83,85 dengan kriteria baik karena terletak pada interval $75 \leq \mathrm{B}<95$. Pada siklus II tindakan 1 rata-rata kemampuan pemahaman siswa 81,1 dan pada tindakan 2 mencapai 86,6 terletak pada interval $75 \leq \mathrm{B}<$ 95 dengan kategori baik. Ketuntasan klasikalnya mencapai 100\%. Hal ini berarti sudah semua siswa dalam kelas yang mencapai ketuntasan individu. Pembelajaran dengan model Mastery Learning menyajikan suatu cara yang menarik dan ringkas untuk meningkatkan kerja siswa ke tingkat pencapaian suatu pokok bahasan yang lebih memuaskan (Joyce, 2011). Hal ini terlihat dari pencapaian rata-rata pemahaman matematis siswa pada setiap siklus yang meningkat dengan hasil yang memuaskan. Untuk peningkatan rata-rata pemahaman siswa pada setiap siklus dapat terlihat pada gambar 3 berikut.

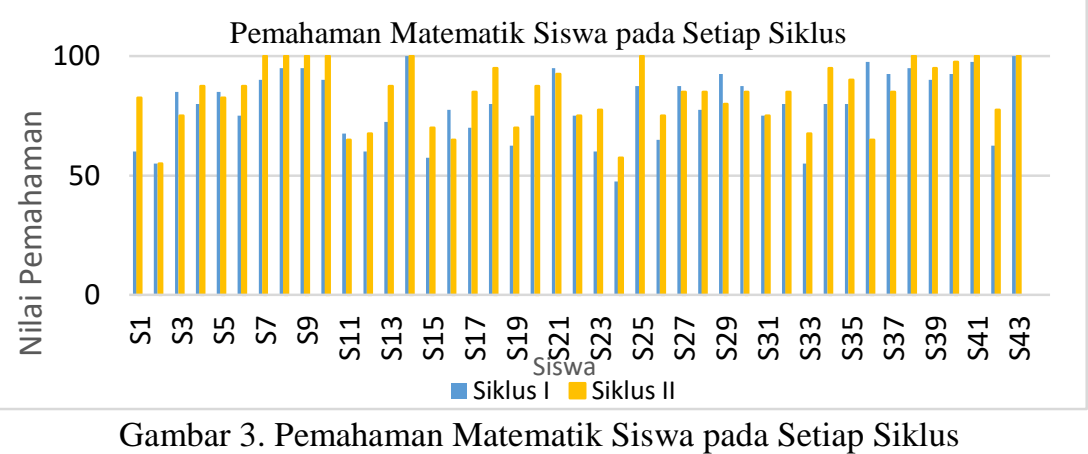

Setelah seluruh siklus pembelajaran berakhir, dilaksanakan tes seluruh siklus yang bertujuan untuk mengetahui kemampuan pemahaman siswa setelah mengikuti pembelajaran dengan menggunakan model Mastery Learning. pada tes akhir (post test) didapat data bahwa siswa yang tuntas sebanyak 41 siswa $(95,3 \%)$ dan 2 siswa $(4,7 \%)$ yang tidak tuntas. Pada tes akhir (post test) dua siswa yang tidak tuntas, hal ini diakibatkan oleh 
beberapa faktor. Pertama, kondisi kelompok yang kurang kondusif saat pembelajaran yang mengakibatkan menurunnya konsentrasi belajar siswa. Kedua, siswa kurang teliti dalam mengerjakan soal, hal ini mengakibatkan berkurangnya poin penilaian. Contohnya pada saat memeriksa lembar jawaban siswa, masih menemukan ada beberapa siswa yang masih tertukar antara menentukan FPB dan KPK. Untuk peningkatan rata-rata pemahaman matematis pada setiap siklus dan tes akhir dapat dilihat pada gambar 4.

Peningkatan Pemahaman Matematik

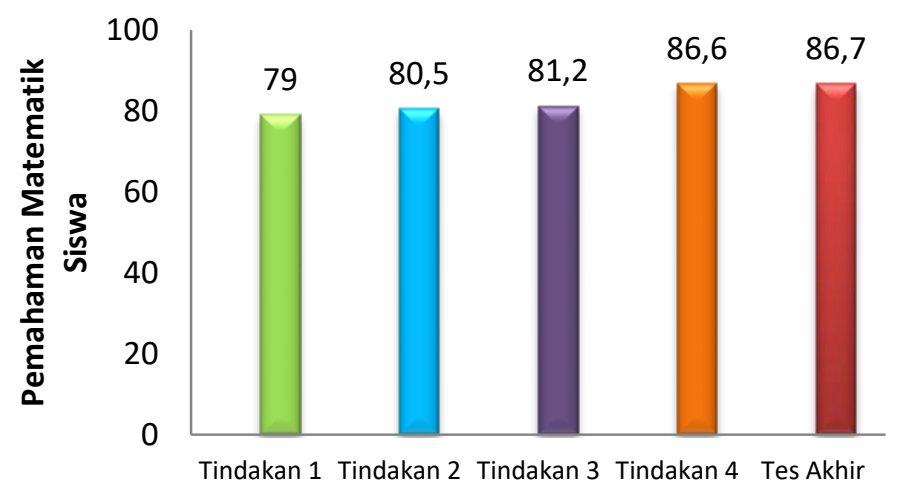

Gambar 4. Peningkataan Pemahaman Matematis Setiap Tindakan

Analisis

Berdasarkan hasil penelitian, aktivitas siswa saat pelaksanaan pembelajaran dengan model Mastery Learning pada tindakan 2 siklus II aktivitas siswa meningkat menjadi 90\% dengan kategori sangat baik dan aktivitas guru menjadi 100\% dengan kategori sangat baik. Ini berarti guru sebagai fasilitator sudah dapat membimbing dan memotivasi siswa untuk lebih aktif dalam pembelajaran dan siswa telah mampu melakukan tugasnya serta antusias saat pembelajaran berlangsung.

Rata-rata kemampuan pemahaman siswa dengan penerapan model Mastery Learning pada setiap siklusnya dan pada tes akhir (post test) dapat terlihat pada gambar 5 berikut.

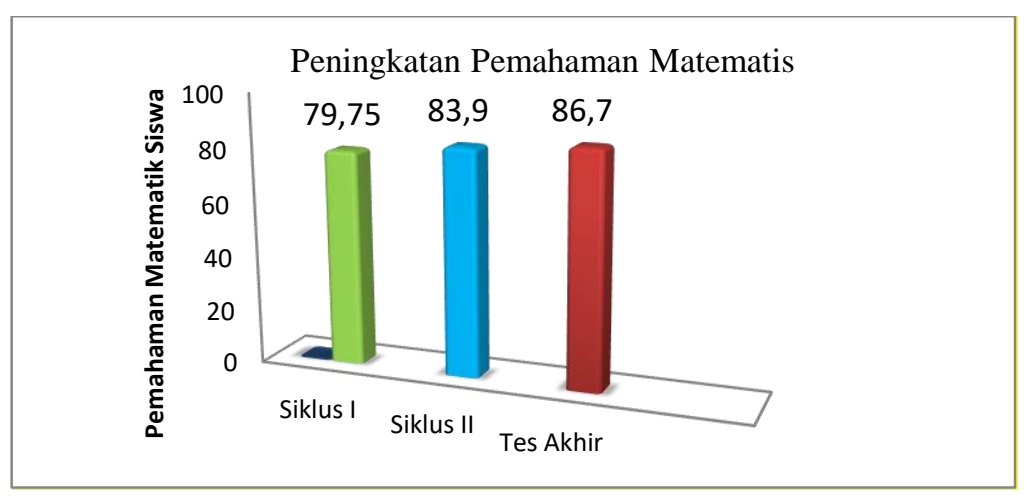

Gambar 5. Peningkataan Pemahaman Matematis Secara Keseluruhan

Berdasarkan gambar diagram batang diatas, dapat diketahui bahwa pemahaman matematik siswa mengalami peningkatan pada tindakan 1 nilai rata-rata pemahaman matematik siswa 79,75 lalu meningkat pada tes akhir (post test) menjadi 86,7. Dengan diterapkannya model Mastery Learning dalam pembelajaran matematika di MIN 1 Kota Bandung ini memberikan dampak positif dimana nilai siswa yang awalnya mengalami perbedaan yang sangat signifikan antara siswa dengan kemampuan pemahaman tinggi dan pemahaman rendah menjadi tidak terlalu jauh perbedaanya. Menurut Ihendinihu (Uchechi, 
2013) berdasarkan hasil penelitian Model Mastery Learning meningkatkan prestasi siswa dan menjembatani kesenjangan antara siswa dengan kemampuan pemahaman tinggi dan rendah dalam matematika. Begitupun dengan penelitian oleh Guzver Yildiran dan Emin Aydin (Yildiran, 2005) mengatakan bahwa Mastery Learning dapat meningkatkan level prestasi belajar siswa dan sikap belajar mereka menjadi lebih positif. Sama halnya dengan penelitian yang dilakukan oleh Kristina Ghultom dan Jaya Dwi Putra (Ghultom, 2016) bahwa terdapat perbedaan antara pembelajaran model Mastery Learning dan pembelajaran konvensional terhadap hasil belajar matematika, dengan hasil pembelajaran dengan model Mastery Learning lebih unggul. Sejalan dengan tiga penelitian yang tadi telah disebutkan, pada penelitian ini penerapan model Mastery Learning juga dapat meningkatkan kemampuan pemahaman khususnya pemahaman matematik siswa, walaupun pada tes siklus II dan tes akhir (post test) kenaikannya tidak terlalu signifikan tetapi proses pembelajaran menjadi lebih aktif serta pemahaman siswa menjadi lebih baik dari sebelum diterapkannya model Mastery Learning.

Kesimpulan dari penelitian tindakan kelas ini dikatakan sudah berhasil karena terbukti terjadi peningkatan pemahaman matematik dari setiap siklusnya melebihi nilai KKM yang ditentukan oleh sekolah dimana pada tes akhir (post test) rata-rata pemahaman matematik siswa mencapai nilai 86,7. Sehingga hipotesis tindakan yang diajukan peneliti terjawab dengan simpulan akhir bahwa penerapan model Mastery Learning dapat meningkatkan kemampuan pemahaman matematik siswa pokok bahasan KPK dan FPB

\section{KESIMPULAN}

Berdasarkan hasil penelitian dan diskusi diatas, maka dapat diambil kesimpulan bahwa keterlaksanaan penerapan pembelajaran dengan menggunakan model Mastery Learning pada setiap siklusnya meningkat dengan baik, terlihat pada akhir siklus aktivitas siswa 88\% dan aktivitas guru 94\% dengan kategori sangat baik. Hal ini membuktikan bahwa penerapan model Mastery Learning dapat membuat proses pembelajaran lebih efektif. Sedangkan peningkatan kemampuan pemahaman matematik siswa dengan menggunakan model Mastery Learnig mengalami peningkatan pada setiap siklusnya. Ketuntasan klasikal pada siklus II sebesar 89,55\% dengan nilai 83,85 berada diantara $75 \leq \mathrm{B}<95$, termasuk kedalam kategori baik. Dengan demikian peningkatan pemahaman matematik siswa dari siklus I ke siklus II selama proses pembelajaran dinyatakan meningkat dengan kategori baik. Selain itu, kemampuan pemahaman matematik siswa pada akhir siklus didapat dari hasil analisis tes akhir siklus (posttest) setelah diterapkan model Mastery Learning diperoleh bahwa ketuntasan klasikal pada akhir siklus sebesar 95,3\% dengan nilai rata-rata siswa 86,7 berada diantara $75 \leq \mathrm{B}<95$, dengan demikian rata-rata pemahaman matematik siswa pada akhir siklus masuk dalam kategori baik, sehingga dapat dikatakan model Mastery Learning dapat meningkatkan kemampuan pemahaman matematik siswa. Dalam pembelajaran matematika yang abstrak khususnya di Madrasah Ibtidaiyah, sudah seharusnya menggunakan model pembelajaran yang bisa membuat siswa terbiasa dan pahamn dengan materi matematika yang diajarkan. Maka, model Mastery Learning patut dijadikan salah satu model andalan yang dapat digunakan oleh guru-guru matematika di Madrasah Ibtidaiyah. 


\section{DAFTAR PUSTAKA}

Emzir. (2013). Metodologi Penelitian Pendidikan. Jakarta: Raja Grafindo Persada.

Groen, Layna. et al. 2015. The Mathematics Problem and Mastery Learning for First-Year, Undergraduate STEM Students, International Journal of Learning, Teaching and Educational Research, 141-160.

Ghultom, Kristina dan Putra, D. Jaya. (2016). Pengaruh Penerapan Model Mastery Learning Terhadap Hasil Belajar Matematika Siswa Kelas VII SMPN 10 Batam Tahun Pelajaran 2014/2015. Jurnal PHYTAGHORAS, 74-79.

Ihendinihu Uchechi E. (2013). Enhancing Mathematics Achievement of Secondary School Students Using Mastery Learning Approach, Journal of Emerging Trends in Educational Research and Policy Studies JETERAPS, 848-854.

Joyce\& Weil. (2009). Models of Teaching Model-model Pengajaran Edisi Kedelapan. Yogyakarta: Pustaka Belajar. Penerjemah: Achmad Fawaid dan Ateilla Mirza.

Lestari, Karunia Eka. (2015). Penelitian Pendidikan Matematika. Bandung: PT Refika Aditama.

Purwanto, Ngalim. (2012). Prinsip-prinsip dan Teknik Evaluasi Pembelajaran. Bandung: PT Remaja Rosdakarya.

Yildiran, Guzver dan Emin, Aydin. (2005). The Effects of Mastery Learning and Cooperative, Competitive and Individualistic Learning Environment Organizations on Achievement and Attitudes in Mathematics, Journal of the Korea Society of Mathematical Education Series D: Research in Mathematical Education, 55-72. 